\title{
Article \\ Effects of Integrated and Organic Management on Strawberry (cv. Camarosa) Plant Growth, Nutrition, Fruit Yield, Quality, Nutraceutical Characteristics, and Soil Fertility Status
}

\author{
Peter Anargyrou Roussos ${ }^{1}$ * , Athanassios Triantafillidis ${ }^{1}$, Evaggelos Kepolas ${ }^{1}$, Panagiotis Peppas ${ }^{2}$, \\ Anastassia Piou ${ }^{2}$, Maria Zoti ${ }^{3}$ and Dionisios Gasparatos ${ }^{2, *}$ (D) \\ 1 Laboratory of Pomology, Department of Crop Science, Agricultural University of Athens, Iera Odos 75, \\ 11855 Athens, Greece; auapom@yahoo.gr (A.T.); auapom@gmail.com (E.K.) \\ 2 Laboratory of Soil Science and Agricultural Chemistry, Agricultural University of Athens, Iera Odos 75, \\ 11855 Athens, Greece; expaua@gmail.com (P.P.); diongas@yahoo.gr (A.P.) \\ 3 General Directory of Agriculture, Ministry of Rural Development and Food, 10176 Athens, Greece; \\ mzoti@minagric.gr \\ * Correspondence: roussosp@aua.gr (P.A.R.); gasparatos@aua.gr (D.G.)
}

check for updates

Citation: Roussos, P.A.; Triantafillidis, A.; Kepolas, E.; Peppas, P.; Piou, A.; Zoti, M.; Gasparatos, D. Effects of Integrated and Organic Management on Strawberry (cv. Camarosa) Plant Growth, Nutrition, Fruit Yield, Quality, Nutraceutical Characteristics, and Soil Fertility Status. Horticulturae 2022, 8, 184. https://doi.org/ $10.3390 /$ horticulturae 8020184

Academic Editors: Othmane Merah, Purushothaman Chirakkuzhyil Abhilash, Magdi T. Abdelhamid, Hailin Zhang and Bachar Zebib

Received: 24 January 2022

Accepted: 18 February 2022

Published: 21 February 2022

Publisher's Note: MDPI stays neutral with regard to jurisdictional claims in published maps and institutional affiliations.

Copyright: (C) 2022 by the authors. Licensee MDPI, Basel, Switzerland. This article is an open access article distributed under the terms and conditions of the Creative Commons Attribution (CC BY) license (https:// creativecommons.org/licenses/by/ $4.0 /$ )

\begin{abstract}
Strawberry plants (cv. Camarosa) were cultivated under organic (ORG) and integrated management (INT) practices to assess possible differences in plant growth, fruit production and quality, soil fertility, and plant nutrition. Two integrated fertilizer schemes were used, differentiating based on the origin of the major organic fertilizer used, i.e., chicken manure (I-ACT) versus fermented fungal biomass (I-AGR). Plant growth was higher under I-ACT treatment, whereas leaf area did not differ among treatments. The two integrated schemes resulted in higher fruit production. The organoleptic characteristics of the fruits did not differ, and this was also confirmed by a taste panel. The antioxidant capacity and flavanol concentration of organically produced fruits were higher, as well as fruit carbohydrate and total organic acid concentration. Leaf nitrogen concentration was higher under I-ACT, followed by ORG. I-ACT resulted in high leaf potassium concentration, as well as iron and manganese (together with I-AGR). Under ORG management, soil EC was found to be lower, whereas soil available phosphorus concentration was highest. Discriminant analysis taking into account fruit quality and phytochemical properties distinguished ORG management from the two integrated management practices, and when soil properties and leaf nutrient concentration were considered; all three systems were separated, indicating that the type of fertilizers used plays a significant role.
\end{abstract}

Keywords: fruit quality; integrated soil fertility management; plant nutrition; phenolics; phytochemicals; sustainability; taste panel

\section{Introduction}

Strawberry is one of the most important berry fruits, consumed worldwide, with great acceptance by most consumers [1]. It is characterized by a pleasant taste, a delicate flavor, and attractive color, which, altogether, contribute to its great appeal. Besides its great taste and other organoleptic characteristics, strawberry can be considered as a functional fruit, since it contains essential nutrients, as well as considerable amounts of phytochemicals, contributing much to human health and well-being [1,2]. Among these phytochemicals, anthocyanins (mainly pelargonidin-3-glucoside and, secondarily, cyanidin-3-glucoside) and phenolic compounds, along with ascorbic acid, are the major constituents of the fruit, which give it its antioxidant, anticarcinogenic, anti-inflammatory, and antineurodegenerative biological properties [1-3].

Strawberry fruit quality is determined based on fruit size and color development, whereas consumer acceptance is based on taste, texture, and flavor [4,5]. Sugars and organic 
acids are the major fruit constituents responsible for the overall strawberry taste, since their balance determines the sweetness and pleasant taste of the fruit [6]. The cultivar is the major factor influencing fruit properties (both organoleptic and nutritional), whereas the climate and cultivation practices also play an important role [2,3]. Among the cultivation practices that may have an important role in strawberry yield and fruit quality is the adaptation of conventional, organic, or integrated practices $[7,8]$.

In modern agriculture, the cultivation systems adopted by farmers are classified into three categories, i.e., conventional, organic (biological or ecological), and integrated farm management [2,9-11]. The factor used as a distinction tool among the three systems is the use of mineral fertilizers and pesticides, the implementation of organic matter in the management system, and the impact of the employed cultivation practices on the environment [11]. Conventional management is a system aiming at high yields through the extensive use of chemical fertilizers, pesticides, and tillage practices in order to increase profits. Organic cultivation is based on environmental respect and aims at the sustainability of the entire production system (soil health, ecosystem, and people) based on the implementation of practices such as no-tillage, crop rotation, use of organic materials as sources of nutrients, and biological methods of pest and disease control [7]. On the other hand, integrated management has positioned itself in the middle of the previously described cultivation practices, as it relies both on mineral and organic sources of nutrients, as well as a logical use of pesticides based on their pre-harvest interval application, aiming at minimal pesticide residues and high yields of good-quality products [3]. In other words, it combines the structural elements of conventional agriculture (proper use of pesticides, sustainable fertilizer management, and minimum tillage) with the fundamentals of organic management (use of organic materials and sustainability of the entire cultivation system, called the agroecosystem, promoting food safety) [7].

Nowadays, there is growing consumer awareness of both healthier cultivation products and environmental sustainability [5,12]. As a result, organic products are becoming increasingly popular, as there is a lot of people claiming that organic foods promote human health more than conventionally produced food. Nonetheless, there are also others claiming the exact opposite, and many more doubt if there is any difference at all [2,7]. For these reasons, a great deal of research has been employed on the comparison between conventional and organic cultivation practices based on fruit quality and functionality. There have been many reports wherein organically produced fruits or vegetables have been found to have greater amounts of flavonoids and ascorbic acid than conventionally produced fruits and vegetables [8]. On the other hand, some studies have reported that there is not sufficient evidence to be driven to valid conclusions, as the scientific research has not proven the undoubted superiority of organic foods $[13,14]$. This is further supported by studies wherein similar or even lower contents of phenolic compounds have been detected in organic products $[15,16]$. The only sure thing is that organic products do not contain any pesticide residues, whereas this is probably not the case for conventional products $[16,17]$.

Concerning strawberry culture, there are some studies wherein organically produced strawberry fruits exhibited higher antiproliferative activity against colon and breast cancer cells than did extracts from conventional strawberries [18], probably as a result of the higher content of phenolic compound $[7,9,16]$. Similarly, ascorbic acid content was found to be higher in organically produced strawberries compared to conventionally grown ones [6,7] also contributing to the higher antioxidant capacity measured.

Organically produced strawberries have been also found to have higher dry weight than conventional ones [19], as well as more intense coloration [5,6,19] due to higher anthocyanin content. Furthermore, total soluble solids (TSS) were found to be in higher concentration in organically produced strawberries, whereas titratable acidity (TA) was lower, contributing to a better taste compared to conventional fruits [19]. Even with so many reports supporting superior strawberry quality when grown organically compared to conventional practices, there are still not enough data to certify the overall sensory and compositional superiority of organically produced strawberries [15,20,21]. 
While there are many studies comparing strawberry fruit quality produced under organic or conventional practices, data on the comparison between integrated and organic strawberry cultivation are quite scarce [10]. Integrated management presents an intermediate approach between conventional and organic cultivation, respecting both human and environmental safety. Therefore, the present research aimed to investigate whether there are any significant differences between organically grown strawberries and those grown under integrated management (using two organic fertilizers of entirely different origin, i.e., chicken manure and fermented mycelium) in terms of (a) yield and fruit quality, (b) fruit functional properties, (c) plant growth and plant nutrition, and (d) soil fertility status.

\section{Materials and Methods}

\subsection{Plant Material}

Fresh, bare-rooted Camarosa cultivar strawberry plants were used (purchased from Georion Ltd. (Ilia County, Greece)) in this study.

A preliminary experiment took place wherein plants were cultivated under organic cultivation management (ORG), using only fertilizers registered for use in organic culture, and under integrated (INT) management, using both organic and chemical fertilizers. The yield, physical characteristics (fruit weight and dimensions), and organoleptic characteristics $(\mathrm{pH}$, titratable acidity, and total soluble solids) of the fruit were assessed.

A second, large-scale experiment took place in order to elucidate the effects of INT (two different schemes) and ORG management on plant growth, fruit production and quality, plant nutrition, and soil properties.

In late October (29 October), plants were planted in $5 \mathrm{~L}$ pots containing a sandy loam soil (for details, see soil analysis below) and placed in a glasshouse at the Agricultural University of Athens orchard (Latitude: $37^{\circ} 58^{\prime} \mathrm{N}$, Longitude: $23^{\circ} 32^{\prime} \mathrm{E}$, Altitude: $30 \mathrm{~m}$ above sea level). A total of 36 plants were used per treatment, arranged according to a complete block design, with three replications of twelve plants each. Of these 12 plants per replicate, four were used in the middle of the harvesting period in order to destructively determine the plant-growth indices, as being described.

\subsection{Treatments and Cultivation Practices}

Irrigation was provided manually with a volume of water ranging from 300 to $500 \mathrm{~mL}$ per irrigation event per plant, according to plant needs. All treatments were based on fertilizer programs applied by the farmers in the Ilia region and on the manufacturer's recommendations. The treatments consisted of (1) organic cultivation management (ORG), using only organic fertilizers; (2) integrated cultivation management, using both chemical and organic fertilizers with Agrobiosol 6-2-4 organic fertilizer as the main organic source (distributed by Intrachem SA, Athens, Greece); (I-AGR) and (3) another integrated cultivation management, using Activit 4-3-2 organic fertilizer as the main nutrient organic source (I-ACT) (distributed by Hellafarm SA, Athens, Greece). Based on its label, Activit 4-3-2 is produced from chicken manure with $62 \%$ organic matter and $\mathrm{pH}$ 6.4. Agrobiosol is a product of fungal biomass produced in a biological fermentation process, with as high as $88 \%$ organic matter and $\mathrm{pH} 3.6$. Both products were regularly applied at their registered dose rates.

The fertilizers used in ORG treatment were Guanito $(6-15-3+10 \mathrm{CaO}+2 \mathrm{MgO})($ distributed by Humofert SA, Athens, Greece) with 45\% organic matter at planting, followed by the microbial product Azospir (Azospirillum sp. $1 \times 10^{12} \mathrm{CFU}$ plus Azotobacter sp. $1 \times 10^{12} \mathrm{CFU}$ ) (distributed by Humofert SA, Greece) at planting and during plant growth, Agrobiosol and Activit during plant growth and fruit development, and Sicobio $\left(6-8-15+3 \mathrm{MgO}+10 \mathrm{SO}_{3}\right)$ with $40 \%$ organic matter (distributed by Humofert SA, Greece) during fruit growth and ripening. During flowering, seaweed extracts Acadian SL (distributed by Humofert SA) and Seamac PTC (distributed by Hellafarm SA) were used to promote fruit set. The phytosanitary program comprised the use of azadiractin, potassium salts of fatty acids, and natural pyrethrum. Iron deficiency was controlled by the application 
of an organic product containing $2 \%$ iron plus seaweed extract and amino acids. Overall, $90 \mathrm{~g}$ of Activit plus $45 \mathrm{~g}$ of Agrobiosol was added per plant during the trial.

In the integrated management condition, besides the basic organic products applied (i.e., Agrobiosol and Activit), complementary fertilization included the use of chemical fertilizers 0-60-20 at planting, whereas during plant growth, Entec Solub (a product of Eurochem) was used as a source of nitrogen, and zinc sulfate, 21-21-21 plus micronutrients, and iron chelate were also applied. During fruit set and fruit growth, Brexil Ca (Valagro Srl) was used as a source of Ca, and Solubor DF (distributed by Phytothreptiki SA, Athens, Greece) was applied as a source of B and potassium nitrate. Overall, $180 \mathrm{~g}$ of Activit and $90 \mathrm{~g}$ of Agrobiosol was added per plant during the trial.

The phytosanitary program consisted of applications of milbemectin against mites and deltamethrin against leaf-eating insects and thrips. No other pests or diseases (such as grey mold) infected the plants, probably due to the mild and dry winter. All products were applied at their registered dose rates (for the pesticides) and based on infestation pressure in ORG- and INT-cultivated plants. More specifically, under ORG conditions, pesticides registered for use in organic cultivation were: azadiractin, which was applied in mid-December, late January, mid-February, and late March; natural pyrethrum, applied in late December and mid-January; and potassium salts of fatty acids, applied in late December, late January, mid-February, mid-March, and mid-April. Under INT cultivation, deltamethrin was applied in mid-December, abamectin in late December, and milbemectin in late March, whereas potassium salts of fatty acids were applied in late January. During the foliar application pesticides, care was taken to avoid overspray of the nearby plants of different treatment by the use of a plastic curtain and a small-volume handheld sprayer. All pests were successfully controlled under all cultivation practices.

\subsection{Samplings and Plant Weight Parameters}

A total of 4 sampling events took place, each one lasting almost 20 days (starting from early February until mid-May, i.e., three and a half months). At each sampling event, only the fully ripe fruits (based on color development on more than three-quarters of fruit surface) were sampled and immediately transferred to the laboratory, where their physiological characteristics were assessed.

After the last sampling event, ripe strawberry fruits were sampled to perform a taste panel and determine the total weight of fruits during the trial period.

At the middle and at the end of the harvesting period, the above-ground plant weight (AGPW) and root weight, as well as the leaf area, were estimated in order to assess the effects of the different cultivation practices on plant growth during these two designated times. On four plants per replicate (12 plants per treatment), the leaves were photographed on a white background (a white sheet of paper), and the total leaf area was estimated using Image J open source software.

\subsection{Evaluation of Fruit Physiological Attributes}

The weight of each fruit, along with its diameter and length, was recorded using a calibrated balance (Kern 470) and a digital caliper (Starrett, 727 series). According to the European Community legislation on strawberry fruit trade $(843 / 2002)$, fruits were classified into two categories (as a percentage out of the total production) based on fruit diameter: 'Extra', including fruits with a diameter over $25 \mathrm{~mm}$; and 'I+II', including fruits with a diameter between 18 and $25 \mathrm{~mm}$.

Fruit firmness was determined with a penetrometer, using a $5 \mathrm{~mm}$ conical plunger. The firmness was measured at two opposite points at the equatorial sector of the fruit. The dry weight of at least five fruits per plot per sampling event was determined after measuring fruit fresh weight and then drying the fruit in an oven at $70{ }^{\circ} \mathrm{C}$ until constant weight to calculate percentage dry weight.

The color of the fruit was determined at two different areas around the equatorial region using a Minolta CR 300 Reflectance Chroma Meter (Minolta, Osaka, Japan), determining 
the CIE $L^{*}, a^{*}$, and $b^{*}$ values, from which the hue-angle degree (ho $=\arctan \left[b^{*} a^{*-1}\right]$ ) and chroma $\left(\mathrm{C}^{*}=\left[\mathrm{a}^{* 2}+\mathrm{b}^{* 2}\right] 1 / 2\right)$ parameters were calculated. After completing the measurements, the fruit sepals were removed, and the fruits were stored at $-25^{\circ} \mathrm{C}$ for further analyses. When the sampling event (one month) was completed, the fruit lots were homogenized frozen by a food processor, and the pulp was stored in a freezer.

\subsection{Determination of Fruit Organoleptic Characteristics}

Approximately $2 \mathrm{~g}$ of frozen pulp was centrifuged in an Eppendorf tube at $14,000 \times g$ for $5 \mathrm{~min}$, and the supernatant clear juice was assessed for its total soluble solids content (TSS), $\mathrm{pH}$, and titratable acidity (TA). TSS was determined with a Hanna HI96801 digital refractometer and expressed as ${ }^{\circ}$ Brix. TA was determined in a sample of diluted juice with distilled water at a ratio of $1: 50$ by titrating to $\mathrm{pH} 8.2$ using $0.1 \mathrm{~N}$. NaOH and $\mathrm{pH}$ were measured in the same diluted solution.

\subsection{Total Phenol Content, Total Anthocyanin Content, Individual Anthocyanin, and Antioxidant Capacity Determination}

Approximately $0.5 \mathrm{~g}$ of the frozen strawberry pulp was extracted twice with $5 \mathrm{~mL} \mathrm{50 \%}$ $(v / v)$ methanol in an ultrasonic bath for 15 min each time and then centrifuged. After the second centrifugation, the two supernatants were combined and assessed for total phenolic compounds according to Roussos et al. [22]. The total phenols, total o-diphenols, total flavanols, and total flavonoids are expressed as mg equivalent of gallic acid (GAE), caffeic acid (CAE), catechin (CtE), and caffeic acid per g fresh weight, respectively.

For the total anthocyanin content, $0.5 \mathrm{~g}$ of the frozen strawberry pulp was extracted twice with $5 \mathrm{~mL}$ of $100 \%$ methanol acidified with $1 \%(v / v)$ concentrated $\mathrm{HCl}$ for $1 \mathrm{~h}$ at $4{ }^{\circ} \mathrm{C}$ with periodical stirring. After the second centrifugation, the supernatants were combined and used for the determination of both total anthocyanins (by the $\mathrm{pH}$ differentiation method) and individual anthocyanins. The total anthocyanin content was assessed according to Roussos et al. [22] and the results are expressed as pelargonidin 3-glucoside $100 \mathrm{~g}^{-1}$ fresh weight. For the individual anthocyanins, a portion of the supernatant was filtered through a $0.24 \mu \mathrm{m}$ pore size syringe filter and analyzed with an HPLC. The HPLC system (HP1050) was equipped with a UV detector operating at $520 \mathrm{~nm}$ and an Inertsil ODS-3 column $(250 \times 4.6 \mathrm{~mm})$. The mobile phase consisted of acetonitrile-water-acetic acid at a ratio of 1-9-0.3. The analysis took place at $30^{\circ} \mathrm{C}$, and the following flow rate gradient was used: $0-5 \mathrm{~min}$ flow rate at $0.5 \mathrm{~mL} \mathrm{~min}^{-1}$; from $6 \mathrm{~min}$ and onward, the flow rate increased to $1.0 \mathrm{~mL} \mathrm{~min}{ }^{-1}$. The three major anthocyanins found in strawberry fruits (pelargonidin-3-glucoside (Pg-3-gluc), cyanidin-3-glucoside (Cy-3-gluc) and pelargonidin3-rutinoside (Pg-3-rut)) were identified based on their spectra and retention time (only for Cy-3-gluc). The pelargonidin derivatives were quantified using a cyanidin-3-glucoside calibration curve.

The antioxidant capacity of strawberry fruits was evaluated in the juice produced after centrifugation of $1 \mathrm{~g}$ pulp using DPPH and FRAP assays based on the method described by Roussos et al. [22] and expressed as a percentage of control and $\mu \mathrm{mol}$ Trolox equivalents per $\mathrm{mL}$ of juice, respectively.

\subsection{Carbohydrate and Organic Acid Determination}

Carbohydrate extraction was performed according to Roussos et al. [22], separated on a Hamilton HC-75 cation-exchange column, calcium form $\left(\mathrm{Ca}^{2+}\right)(305 \mathrm{~mm} \times 7.8 \mathrm{~mm}$, $9 \mu \mathrm{m})$ (Hamilton, Bonaduz, Switzerland), equilibrated at $80{ }^{\circ} \mathrm{C}$ with water as mobile phase, running at a flow of $0.6 \mathrm{~mL} \mathrm{~min}^{-1}$ and determined using an HP1050 HPLC system equipped with an isocratic pump and a refractive index detector (HP1047A). The three soluble sugars detected were sucrose, glucose, and fructose and were quantified (expressed as $\% w / w$ of fresh weight) using external calibration curves.

The sweetness index (SI) of the fruit was calculated based on the relative amount and sweetness of each detected carbohydrate [23], according to the following formula: 
$\mathrm{SI}=[1.00 *($ glucose concentration $)+1.35 *($ sucrose concentration $)+2.3 *$ (fructose concentration) $]$, as fructose and sucrose are 2.3 and 1.35 times sweeter than glucose, respectively.

Organic acids of the fruits were determined after extraction of approximately $0.5 \mathrm{~g}$ frozen pulp with $5 \mathrm{~mL} \mathrm{3 \%} w / v$ metaphosphoric acid in water (twice) at room temperature for $30 \mathrm{~min}$ with periodical stirring. At the end of each extraction, the solutions were centrifuged for $6 \mathrm{~min}$ at $4000 \times g$, and the supernatants were collected, combined, and filtered through a nylon syringe filter of $0.45 \mu \mathrm{m}$ pore size. Samples were then analyzed by the HPLC described above equipped with a UV detector and operating at $200 \mathrm{~nm}$. Organic acids were separated through a Hypersil ODS column $(250 \times 4.6 \mathrm{~mm})$ with a mobile phase consisting of $0.04 \%$ formic acid in water at a flow rate of $0.8 \mathrm{~mL} \mathrm{~min}{ }^{-1}$ at $35{ }^{\circ} \mathrm{C}$. The identification and quantification of organic acids were based on a five-point calibration curve of external standards (citric, malic, and ascorbic acid).

\subsection{Soil and Plant Analysis}

In mid-May, fully mature, healthy leaves were sampled for nutrient analyses. At the same time, plants were uprooted, and soil samples were taken. The soil samples were airdried, crushed and sieved through a $2 \mathrm{~mm}$ mesh and finally stored in sterile sampling bags. The above-ground plant mass was washed with distilled water and thereafter oven-dried at $70{ }^{\circ} \mathrm{C}$ until constant weight and used for mineral nutrient analysis. Soil and plant samples were analyzed as previously described by Ntanos et al. [24].

\subsection{Taste Panel}

To assess the effects of cultivation management on the overall sensory characteristics of the fruits, a taste panel was organized with 20 panelists (1:1 male:female) who had been previously trained on the specific test. The criteria used to evaluate the sensory attributes of the fruit were: taste, flavor, appearance, firmness, acidity, sweetness, mouth aroma, and taste remaining after swallowing (after taste) on a $0-5$ scale (0, worst or least; 5 , best or most).

\subsection{Trial Design and Statistical Analysis}

The experiment was arranged as a completely randomized block design with three replications of 8 plants per replication (four separate plants were used to evaluate the overall plant growth, leaf nutrient concentration, and soil properties in the middle of the trial period, i.e., 26th of March, through destructive measurement, so they were not used for the quantitative and qualitative evaluation of yield). All samples were analyzed twice, and the derived raw data were analyzed as a one-way ANOVA, with the factor being cultivation management (ORG, I-ACT and I-AGR). Before analysis, the normality of data distribution was checked, and where needed, suitable data transformation was performed. The data were analyzed together (all sampling events) for each measured variable $(n=12)$, and the significant differences were determined based on Tukey HSD test at $\alpha=0.05$. Discriminant analysis was performed to assess whether the three cultivation managements could be distinguished based on either yield characteristics or soil physicochemical properties plus plant nutrient status. Statistical analysis was performed using Statgraphics Centurion XVII (Statpoint Inc., Warrenton, VA, USA).

\section{Results}

\subsection{Effects of Cultivation Management on Yield and Fruit Physicochemical and} Phytochemical Properties

Based on the preliminary trial, INT management resulted in higher mean fruit weight (almost 25\% higher), diameter, and length, without significant yield differences from the ORG-produced fruits, and the organoleptic characteristics of the fruit did not differ either.

During the second, large-scale trial, cultivation management had a significant effect on strawberry yield, as both integrated strategies resulted in higher yields than the organic strategy, with I-ACT presenting significant differences from the latter (Table 1). Fruit 
physiological characteristics, i.e., fruit weight, diameter, length, firmness, and percentage dry weight did not differ among treatments.

Table 1. Effects of cultivation management on yield per plant and fruit physiological characteristics during the experimental period.

\begin{tabular}{cccccccc}
\hline Treatment & $\begin{array}{c}\text { Yield per } \\
\text { Plant } \mathbf{( g )}\end{array}$ & $\begin{array}{c}\text { Mean Fruit } \\
\text { Weight } \mathbf{( g )}\end{array}$ & $\begin{array}{c}\text { Diameter } \\
\mathbf{( m m )}\end{array}$ & $\begin{array}{c}\text { Length } \\
\mathbf{( m m )}\end{array}$ & D/L & $\begin{array}{c}\text { Firmness } \\
(\mathbf{k g})\end{array}$ & $\begin{array}{c}\text { DW } \\
\mathbf{( \% )}\end{array}$ \\
\hline ORG & $256.8 \mathrm{~b}$ & $16.27 \mathrm{a}$ & $34.75 \mathrm{a}$ & $41.54 \mathrm{a}$ & $0.83 \mathrm{a}$ & $0.47 \mathrm{a}$ & $7.54 \mathrm{a}$ \\
I-AGR & $294.8 \mathrm{ab}$ & $16.68 \mathrm{a}$ & $33.99 \mathrm{a}$ & $39.89 \mathrm{a}$ & $0.85 \mathrm{a}$ & $0.46 \mathrm{a}$ & $7.33 \mathrm{a}$ \\
I-ACT & $344.1 \mathrm{a}$ & $16.07 \mathrm{a}$ & $31.01 \mathrm{a}$ & $36.82 \mathrm{a}$ & $0.84 \mathrm{a}$ & $0.46 \mathrm{a}$ & $7.76 \mathrm{a}$ \\
\hline
\end{tabular}

Abbreviations: ORG, organic; I-AGR, integrated based on Agrobiosol amendment; I-ACT, integrated based on Activit amendment; D/L, diameter-length ratio; DW, dry weight. Means within the same column followed by different letters represent statistical significant differences based on Tukey HSD multiple range test at $\mathrm{a}=0.05$.

Strawberry fruits under all cultivation management strategies presented similar color attributes, as can be seen in Table 2. However, the number of fruits per plant was significantly higher under the I-ACT treatment compared to the other two treatments, and the percentage of fruits classified in the Extra category did not present any significant difference among treatments.

Table 2. Effects of cultivation management on fruit color parameters and category classification.

\begin{tabular}{ccccccc}
\hline Treatment & Hue & Chroma & L & $\begin{array}{c}\text { Fruit Number } \\
\text { per Plant }\end{array}$ & Extra (\%) & I\&II (\%) \\
\hline ORG & $30.01 \mathrm{a}$ & $40.35 \mathrm{a}$ & $35.17 \mathrm{a}$ & $16.29 \mathrm{~b}$ & $89.63 \mathrm{a}$ & $10.01 \mathrm{a}$ \\
I-AGR & $29.26 \mathrm{a}$ & $40.25 \mathrm{a}$ & $34.93 \mathrm{a}$ & $17.41 \mathrm{~b}$ & $91.14 \mathrm{a}$ & $8.85 \mathrm{a}$ \\
I-ACT & $29.52 \mathrm{a}$ & $41.10 \mathrm{a}$ & $35.44 \mathrm{a}$ & $22.58 \mathrm{a}$ & $85.22 \mathrm{a}$ & $14.77 \mathrm{a}$ \\
\hline
\end{tabular}

Abbreviations: ORG, organic; I-AGR, integrated based on Agrobiosol amendment; I-ACT, integrated based on Activit amendment; L*, color lightness; I\&II, strawberry fruit quality grade. Means within the same column followed by different letters represent statistically significant differences based on Tukey HSD multiple range test at $\mathrm{a}=0.05$.

Fruit organoleptic characteristics did not differ among treatments, as the titratable acidity was close to $0.85 \% w / w /$ citric acid and TSS ranged from 6.99 to 7.40 (Table 3).

Table 3. Effects of cultivation management on fruit organoleptic characteristics (TA, titratable acidity; TSS, total soluble solids).

\begin{tabular}{ccccc}
\hline Treatment & $\begin{array}{c}\text { TA } \\
(\% \boldsymbol{w} / \boldsymbol{w} \text { Citric Acid })\end{array}$ & $\begin{array}{c}\text { TSS } \\
\left(\mathbf{}{ }^{\mathbf{B}} \mathbf{B r i x}\right)\end{array}$ & $\mathbf{p H}$ & TSS/TA \\
\hline ORG & $0.85 \mathrm{a}$ & $7.35 \mathrm{a}$ & $3.54 \mathrm{a}$ & $8.79 \mathrm{a}$ \\
I-AGR & $0.86 \mathrm{a}$ & $6.99 \mathrm{a}$ & $3.61 \mathrm{a}$ & $8.28 \mathrm{a}$ \\
I-ACT & $0.85 \mathrm{a}$ & $7.40 \mathrm{a}$ & $3.60 \mathrm{a}$ & $8.80 \mathrm{a}$ \\
\hline
\end{tabular}

Abbreviations: ORG, organic; I-AGR, integrated based on Agrobiosol amendment; I-ACT, integrated based on Activit amendment. Means within the same column followed by different letters represent statistically significant differences based on Tukey HSD multiple range test at $\mathrm{a}=0.05$.

The concentration of total phenolic compounds, total o-diphenols, and total flavonoids did not differ among treatments, and organically produced fruits exhibited significantly higher total flavanol concentration than those produced by integrated management (Table 4). Similarly, the antioxidant capacity of the fruits, based on FRAP assay, was higher in organically produced fruits and did not differ among cultivation management strategies when measured by DPPH assay.

Strawberry fruits produced under the various cultivation systems did not present significant differences concerning their anthocyanin concentrations (Table 5). Pelargonidin3-glucoside was the predominant anthocyanin in the fruits. 
Table 4. Effects of cultivation management on fruit total phenol (mg gallic acid equiv. $\left.100 \mathrm{~g}^{-1} \mathrm{~F} . \mathrm{W}.\right)$, total o-diphenol (mg caffeic acid equiv. $100 \mathrm{~g}^{-1}$ F.W.), total flavonoids (mg caffeic acid equiv. $100 \mathrm{~g}^{-1}$ F.W.), total flavanol concentration ( $\mathrm{mg}$ catechin equiv. $100 \mathrm{~g}^{-1}$ F.W.), and antioxidant capacity measured by DPPH (expressed as percentage of control) and FRAP assays (expressed as $\mu \mathrm{mol}$ Trolox $100 \mathrm{~g}^{-1}$ fresh weight).

\begin{tabular}{ccccccc}
\hline Treatment & $\begin{array}{c}\text { Total } \\
\text { Phenols }\end{array}$ & $\begin{array}{c}\text { Total } \\
\text { o-Diphenols }\end{array}$ & $\begin{array}{c}\text { Total } \\
\text { Flavonoids }\end{array}$ & $\begin{array}{c}\text { Total } \\
\text { Flavanols }\end{array}$ & DPPH & FRAP \\
\hline ORG & $174.4 \mathrm{a}$ & $27.28 \mathrm{a}$ & $249.2 \mathrm{a}$ & $28.28 \mathrm{a}$ & $53.06 \mathrm{a}$ & $19.05 \mathrm{a}$ \\
I-AGR & $171.9 \mathrm{a}$ & $23.63 \mathrm{a}$ & $210.5 \mathrm{a}$ & $17.62 \mathrm{~b}$ & $52.02 \mathrm{a}$ & $13.89 \mathrm{~b}$ \\
I-ACT & $167.7 \mathrm{a}$ & $22.75 \mathrm{a}$ & $209.6 \mathrm{a}$ & $17.29 \mathrm{~b}$ & $56.41 \mathrm{a}$ & $14.22 \mathrm{~b}$
\end{tabular}

Abbreviations: ORG, organic; I-AGR, integrated based on Agrobiosol amendment; I-ACT, integrated based on Activit amendment; DPPH, diphenyl picryl hydrazy antioxidant assay; FRAP, ferric reducing antioxidant power Means within the same column followed by different letters represent statistically significant differences based on Tukey HSD multiple range test at $\mathrm{a}=0.05$.

Table 5. Effects of cultivation management on the concentration of total anthocyanins (TANTHO) (mg $100 \mathrm{~g}^{-1}$ F.W.), pelargonidin-3-rutinoside (Pg-3-gluc), pelargonidin-3-glucoside (Pg-3-gluc), and cyaniding-3-glucoside (Cy-3-gluc) $\left(\mu \mathrm{g} \mathrm{g}^{-1}\right.$ F.W.) in strawberry fruits.

\begin{tabular}{ccccc}
\hline Treatment & TANTHO & Cy-3-gluc & Pg-3-gluc & Pg-3-rut \\
\hline ORG & $16.478 \mathrm{a}$ & $50.14 \mathrm{a}$ & $488.0 \mathrm{a}$ & $75.65 \mathrm{a}$ \\
I-AGR & $16.67 \mathrm{a}$ & $57.95 \mathrm{a}$ & $541.5 \mathrm{a}$ & $80.97 \mathrm{a}$ \\
I-ACT & $15.63 \mathrm{a}$ & $55.31 \mathrm{a}$ & $491.4 \mathrm{a}$ & $80.90 \mathrm{a}$
\end{tabular}

Abbreviations: ORG, organic; I-AGR, integrated based on Agrobiosol amendment; I-ACT, integrated based on Activit amendment; D/L, diameter-length ratio; DW, dry weight. Means within the same column followed by different letters represent statistically significant differences based on Tukey HSD multiple range test at $\mathrm{a}=0.05$.

Sugar concentration in the fruit was significantly affected by cultivation management, as I-AGR resulted in fruit with significantly lower glucose, fructose. and total sugars concentration, as well as sweetness index, compared to ORG (Table 6).

Table 6. Effects of cultivation management on fruit carbohydrate concentration (\% F.W.) and sweetness index of the fruit.

\begin{tabular}{cccccc}
\hline Treatment & SUC & GLUC & FRUCT & TSUGS & SI \\
\hline ORG & $1.78 \mathrm{a}$ & $1.75 \mathrm{a}$ & $1.89 \mathrm{a}$ & $5.43 \mathrm{a}$ & $8.52 \mathrm{a}$ \\
I-AGR & $1.53 \mathrm{a}$ & $1.45 \mathrm{~b}$ & $1.62 \mathrm{~b}$ & $4.60 \mathrm{~b}$ & $7.24 \mathrm{~b}$ \\
I-ACT & $1.81 \mathrm{a}$ & $1.58 \mathrm{ab}$ & $1.68 \mathrm{ab}$ & $5.08 \mathrm{ab}$ & $7.91 \mathrm{ab}$ \\
\hline
\end{tabular}

Abbreviations: ORG, organic; I-AGR, integrated based on Agrobiosol amendment; I-ACT, integrated based on Activit amendment; SUC, sucrose; GLUC, glucose; FRUCT, fructose; TSUGS, total sugars; SI, sweetness index Means within the same column followed by different letters represent statistically significant differences based on Tukey HSD multiple range test at $\mathrm{a}=0.05$.

Individual organic acid concentration did not differ among treatments, although the total organic acid concentration in the fruit was higher under organic management, although there was no significant difference compared to I-ACT, whereas the sour index was lowest under I-AGR, with a significant difference compared to I-ACT (Table 7).

Table 7. Effects of cultivation management on fruit organic acid concentration $\left(\mathrm{mg} \mathrm{g}^{-1}\right)$ and sour index.

\begin{tabular}{cccccc}
\hline Treatment & Malic Acid & Citric Acid & $\begin{array}{c}\text { Ascorbic } \\
\text { Acid }\end{array}$ & $\begin{array}{c}\text { Sum of Acids } \\
\text { Determined }\end{array}$ & SOURI \\
\hline ORG & $2.62 \mathrm{a}$ & $10.81 \mathrm{a}$ & $0.13 \mathrm{a}$ & $13.57 \mathrm{a}$ & $5.04 \mathrm{ab}$ \\
I-AGR & $2.30 \mathrm{a}$ & $9.77 \mathrm{a}$ & $0.09 \mathrm{a}$ & $12.17 \mathrm{~b}$ & $4.77 \mathrm{~b}$ \\
I-ACT & $2.58 \mathrm{a}$ & $9.81 \mathrm{a}$ & $0.10 \mathrm{a}$ & $12.49 \mathrm{ab}$ & $5.30 \mathrm{a}$ \\
\hline
\end{tabular}

Abbreviations: ORG, organic; I-AGR, integrated based on Agrobiosol amendment; I-ACT, integrated based on Activit amendment; SOURI, total sugars/citric acid. Means within the same column followed by different letters represent statistically significant differences based on Tukey HSD multiple range test at $\mathrm{a}=0.05$. 
The taste panel results reveal that there were not any significant differences concerning the various taste and perception attributes tested by the panelists, as can be seen in Figure 1.

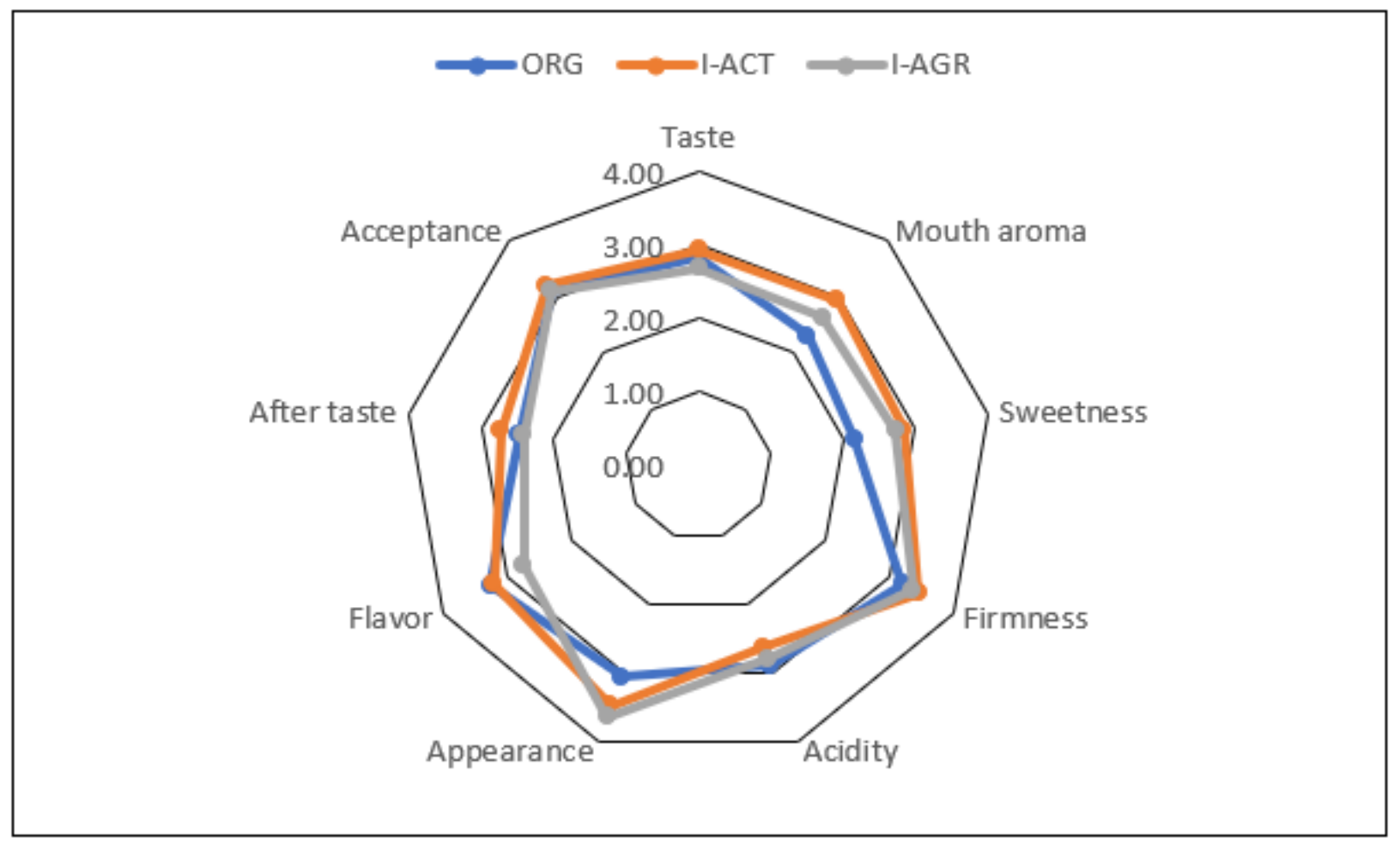

Figure 1. Spider chart of the results of the taste panel based on the taste and perception attributes tested. ORG, organic; I-AGR, integrated based on Agrobiosol amendment; I-ACT, integrated based on Activit amendment.

\subsection{Effects of Cultivation Management on Plant Growth and Nutrient Status}

Plant weight during the second assessment (PW2) was significantly higher under the I-ACT treatment compared to the ORG treatment, and root weight was also higher under I-ACT than ORG treatment (RW2) (Figure 2A). The AGPW-to-root ratio was higher under the ORG treatment during both measurements. Leaf area did not differ among treatments during the first assessments, whereas during the second assessment, plants under I-ACT treatment presented higher leaf area than the other two treatments (Figure 2B).

Cultivation management had a significant effect on plant nutrient status, as significant differences were determined concerning nitrogen, potassium, iron, and manganese concentrations (Table 8). I-ACT resulted in the highest nitrogen concentration in the leaves, followed by ORG and I-AGR. Potassium was found in high concentration in the leaves of the I-ACT-grown plants, with significant differences from the ORG plants. Both iron and manganese were found in higher concentrations in both integrated cultivation management treatments than in the organic treatment. The concentration of other nutrients did not differ among treatments. 

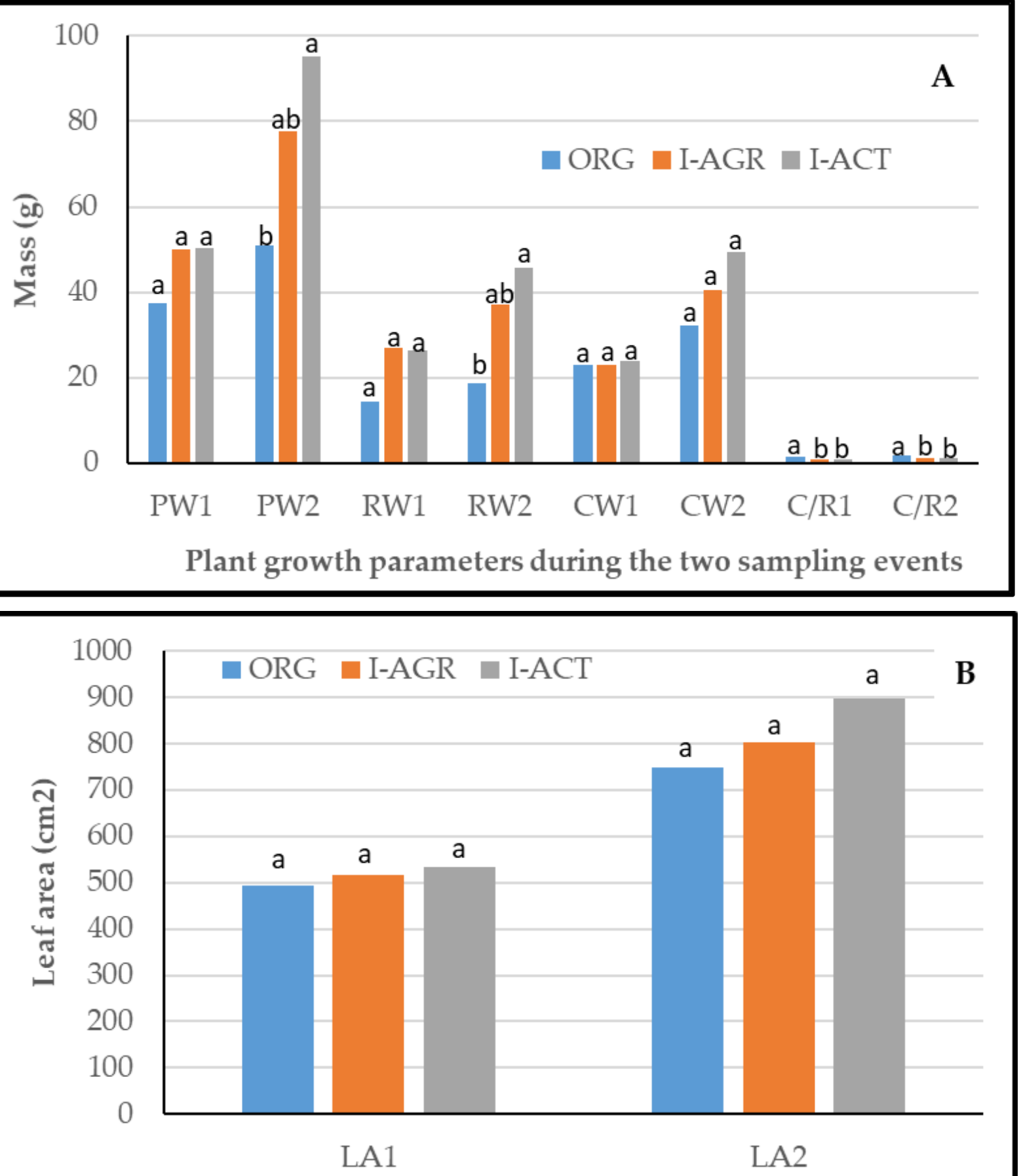

Plant leaf area during the two sampling events

Figure 2. Effect of cultivation management on plant weight (A) and leaf area (B) during the two sampling events (26 of March (1) and 20 of May (2)). PW, plant weight; RW, root weight; CW, above ground plant weight, $\mathrm{C} / \mathrm{R}$, above ground versus root weight; LA, leaf area; ORG, organic; I-AGR, integrated based on Agrobiosol amendment; I-ACT, integrated based on Activit amendment. Different letters above each column within the same parameter evaluated, indicate significant differences among treatments based on Tukey HSD multiple range test at $\mathrm{a}=0.05$. 
Table 8. Effects of cultivation management on leaf nutrient concentration.

\begin{tabular}{ccccccccccc}
\hline \multirow{2}{*}{ Treatment } & $\mathbf{N}$ & $\mathbf{P}$ & $\mathbf{K}$ & $\mathbf{N a}$ & $\mathbf{C a}$ & $\mathbf{M g}$ & $\mathbf{F e}$ & $\mathbf{M n}$ & $\mathbf{C u}$ & $\mathbf{Z n}$ \\
\cline { 2 - 10 } & \multicolumn{9}{c}{$\mathbf{( \% )}$} \\
\hline ORG & $1.88 \mathrm{~b}$ & $0.13 \mathrm{a}$ & $0.86 \mathrm{~b}$ & $0.10 \mathrm{a}$ & $1.75 \mathrm{a}$ & $0.26 \mathrm{a}$ & $67.84 \mathrm{~b}$ & $35.24 \mathrm{~b}$ & $17.2 \mathrm{a}$ & $24.32 \mathrm{a}$ \\
I-AGR & $1.47 \mathrm{c}$ & $0.16 \mathrm{a}$ & $1.42 \mathrm{ab}$ & $0.19 \mathrm{a}$ & $2.56 \mathrm{a}$ & $0.43 \mathrm{a}$ & $128.9 \mathrm{a}$ & $99.82 \mathrm{a}$ & $21.2 \mathrm{a}$ & $24.02 \mathrm{a}$ \\
I-ACT & $2.29 \mathrm{a}$ & $0.19 \mathrm{a}$ & $1.98 \mathrm{a}$ & $0.19 \mathrm{a}$ & $2.00 \mathrm{a}$ & $0.42 \mathrm{a}$ & $125.8 \mathrm{a}$ & $101.56 \mathrm{a}$ & $20.7 \mathrm{a}$ & $27.66 \mathrm{a}$ \\
\hline
\end{tabular}

Abbreviations: ORG, organic; I-AGR, integrated based on Agrobiosol amendment; I-ACT, integrated based on Activit amendment. Means within the same column followed by different letters represent statistically significant differences based on Tukey HSD multiple range test at $\mathrm{a}=0.05$.

\subsection{Effects of Cultivation Management on Soil Properties and Soil Nutrient Status}

Soil physicochemical properties were also influenced by cultivation management, as I-ACT presented higher a soil EC value than the ORG treatment (Table 9) but significantly lower P concentration (Table 10). On the other hand, Na concentration was lowest under ORG treatment, with a significant difference from the I-AGR treatment, which presented the lowest $\mathrm{Zn}$ concentration-lower than that determined in the I-ACT soil (Table 10).

Table 9. Effects of cultivation management on soil properties.

\begin{tabular}{|c|c|c|c|c|c|}
\hline Treatment & $\mathrm{pH}$ & $\begin{array}{c}\mathrm{CaCO}_{3} \\
(\%)\end{array}$ & $\begin{array}{c}\mathrm{EC} \\
\left(\mathrm{mS} \mathrm{cm}^{-1}\right)\end{array}$ & $\begin{array}{l}\text { OM } \\
(\%)\end{array}$ & $\begin{array}{c}\text { CEC } \\
\left(\text { meq } 100 g^{-1}\right)\end{array}$ \\
\hline ORG & $7.52 \mathrm{a}$ & $26.36 \mathrm{a}$ & $3.96 \mathrm{~b}$ & $4.77 \mathrm{a}$ & $21.06 \mathrm{a}$ \\
\hline I-AGR & $7.52 \mathrm{a}$ & $26.46 \mathrm{a}$ & $4.46 \mathrm{ab}$ & $5.07 \mathrm{a}$ & $21.08 \mathrm{a}$ \\
\hline I-ACT & $7.47 \mathrm{a}$ & $25.64 \mathrm{a}$ & $5.2 \mathrm{a}$ & $4.62 \mathrm{a}$ & $21.38 \mathrm{a}$ \\
\hline
\end{tabular}

Abbreviations: ORG, organic; I-AGR, integrated based on Agrobiosol amendment; I-ACT, integrated based on Activit amendment; EC, electrical conductivity; OM, organic matter; $\mathrm{CEC}$, cation exchange capacity. Means within the same column followed by different letters represent statistically significant differences based on Tukey HSD multiple range test at $\mathrm{a}=0.05$.

Table 10. Effects of cultivation management on soil nutrient concentration.

\begin{tabular}{|c|c|c|c|c|c|c|c|c|c|}
\hline \multirow{2}{*}{ Treatments } & $\mathbf{P}$ & K & $\mathrm{Na}$ & $\mathrm{Ca}$ & Mg & $\mathrm{Fe}$ & Mn & $\mathrm{Cu}$ & Zn \\
\hline & $\left(\mathrm{mg} \mathrm{kg}^{-1}\right)$ & \multicolumn{4}{|c|}{$\left(\right.$ meq $\left.100 g^{-1}\right)$} & \multicolumn{4}{|c|}{$\left(\mathrm{mg} \mathrm{kg}^{-1}\right)$} \\
\hline ORG & $109.6 \mathrm{a}$ & $0.79 \mathrm{a}$ & $0.35 \mathrm{~b}$ & $26.83 \mathrm{a}$ & $2.23 \mathrm{a}$ & $3.89 \mathrm{a}$ & $21.08 \mathrm{a}$ & $1.17 \mathrm{a}$ & $3.15 \mathrm{ab}$ \\
\hline I-AGR & $56.9 \mathrm{~b}$ & $0.78 \mathrm{a}$ & $0.46 \mathrm{a}$ & $26.97 \mathrm{a}$ & $2.06 \mathrm{a}$ & $4.08 \mathrm{a}$ & $26.64 \mathrm{a}$ & $0.99 \mathrm{a}$ & $2.62 \mathrm{~b}$ \\
\hline I-ACT & $67.5 \mathrm{~b}$ & $1.04 \mathrm{a}$ & $0.38 \mathrm{ab}$ & $30.62 \mathrm{a}$ & $2.19 a$ & $3.93 \mathrm{a}$ & $27.00 \mathrm{a}$ & $0.99 \mathrm{a}$ & $3.44 \mathrm{a}$ \\
\hline
\end{tabular}

Abbreviations: ORG, organic; I-AGR, integrated based on Agrobiosol amendment; I-ACT, integrated based on Activit amendment. Means within the same column followed by different letters represent statistically significant differences based on Tukey HSD multiple range test at $\mathrm{a}=0.05$.

The discriminant analysis using all the data derived from fruit analysis was able to discriminate the integrated management treatment from the organic treatment, as the latter was located at the positive side of Function 1, whereas the two integrated management systems were on the negative side of Function 1 (Figure 3).

Similarly, the discriminant analysis, which used the soil analysis results and plant nutrient status, was able to distinguish cultivation management treatments, as they were all located in different quadrants of the discriminant plot (Figure 4). Organic and I-ACT treatments were located on the positive side of Function 1, ORG was also located on the positive side of Function 2, and I-ACT was on the negative side of Function 2. On the other hand, I-AGR was located on the negative side of both functions. 


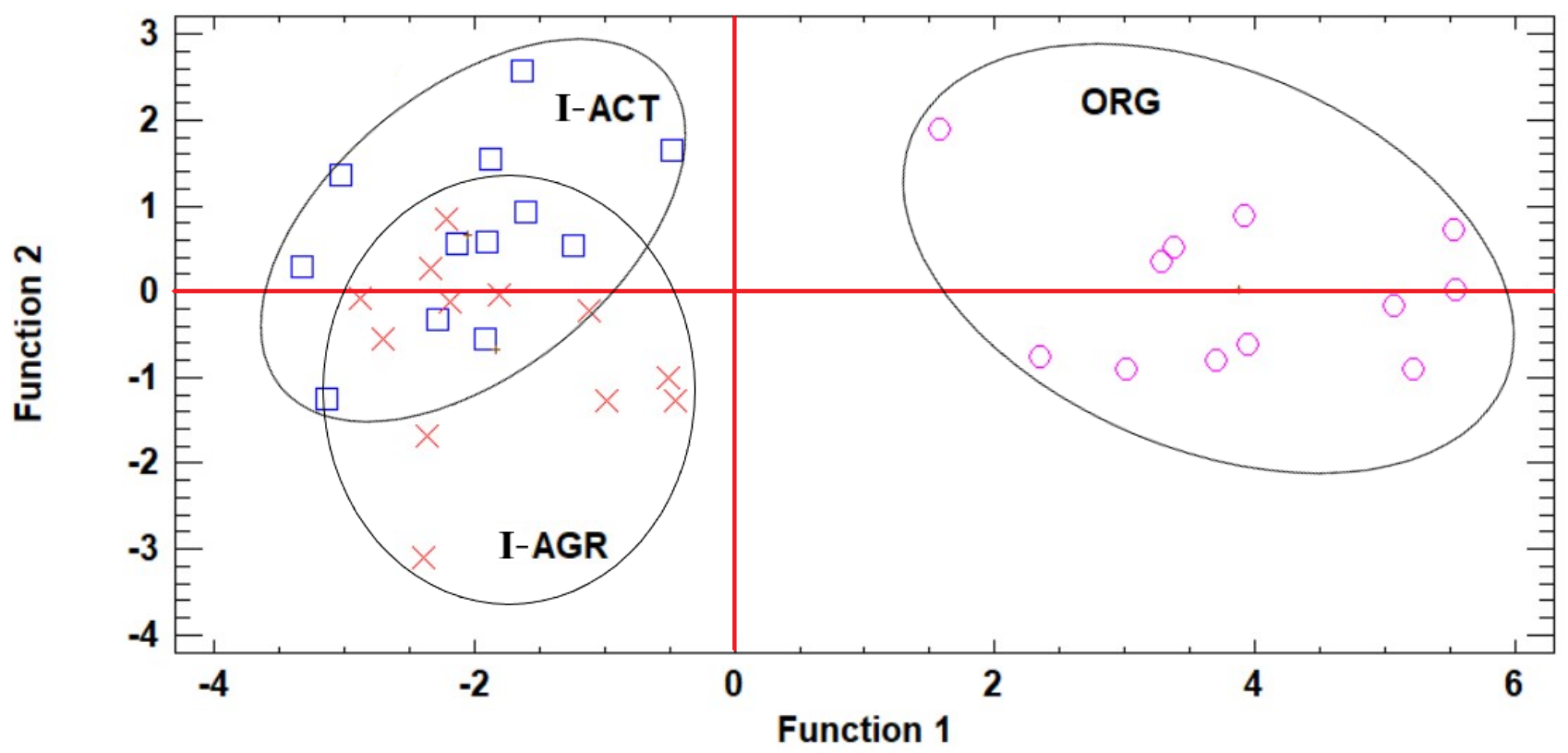

Figure 3. Plot of the discriminant functions produced by the three treatments based on yield, fruit quality, and phytochemical attributes. Abbreviations: ORG, organic; I-AGR, integrated based on Agrobiosol amendment; I-ACT, integrated based on Activit amendment.

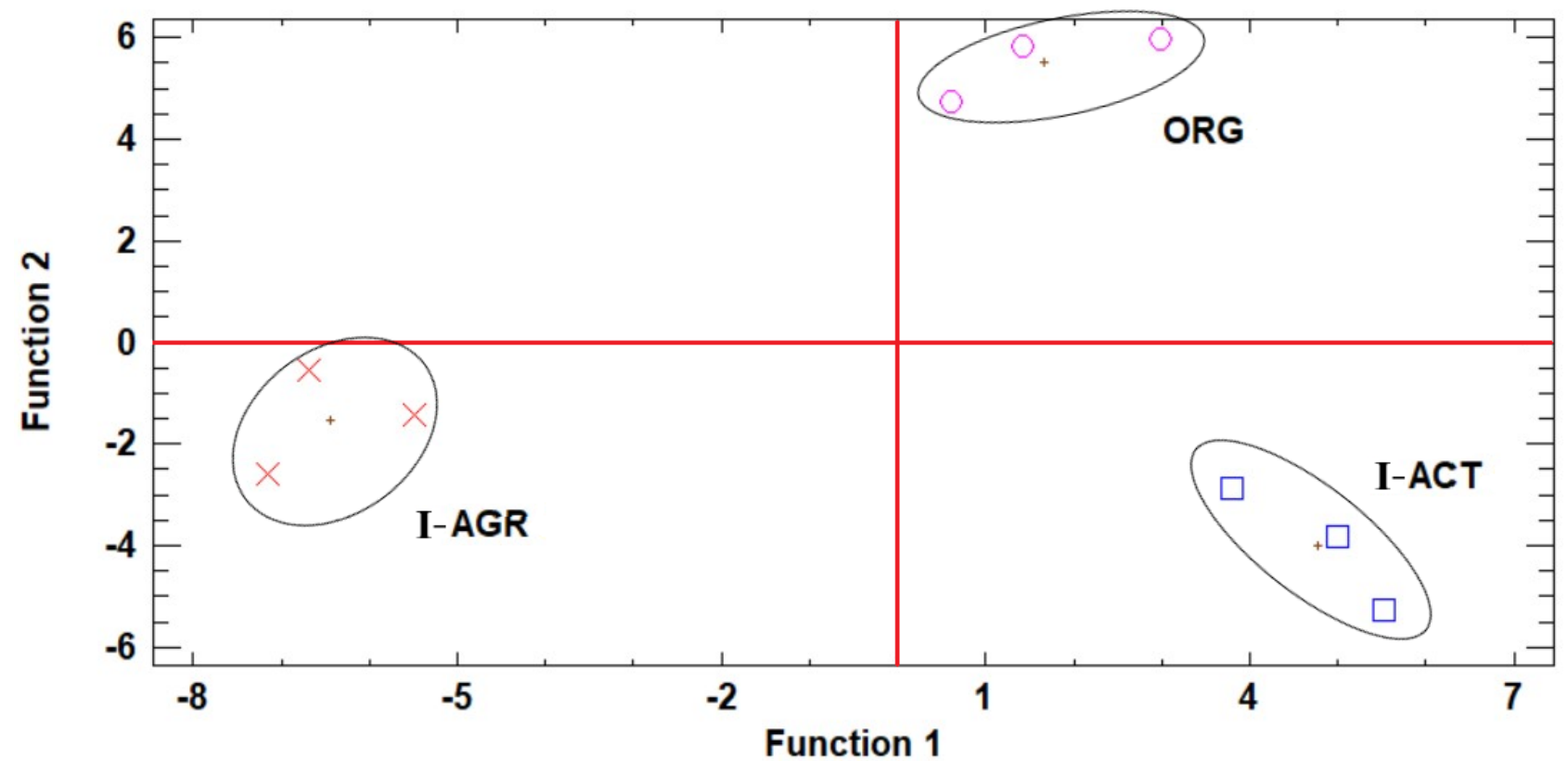

Figure 4. Plot of the discriminant functions produced by the three treatments based on soil characteristics and plant nutrient status. Abbreviations: ORG, organic; I-AGR, integrated based on Agrobiosol amendment; I-ACT, integrated based on Activit amendment.

\section{Discussion}

Cultivation management strongly influenced plant growth and fruit production, as well as soil properties and plant nutrient status, as was clearly shown in the discriminant analysis plots. ORG treatment was clearly distinguished from integrated treatments. Although INT treatments seemed to differentially influence soil properties and plant nutrition, they could not be distinguished based on fruit physiological, organoleptic, or phytochemical properties. 
The yield was significantly higher under I-ACT treatment, followed by I-AGR, and lastly by ORG treatment. Higher yield under conventional management has been reported by other authors [4,25-27]. These difference should not be attributed to any biotic or abiotic stress factor, as all measures were successfully taken to ensure plant health under all treatments. It is assumed that the enhancement of plant yield under the INT management treatment is the result of the faster nutrient absorption of the mineral fertilizers used in INT management, resulting in higher plant growth and leaf area, as indicated in Figure 2. Similar observations have been reported on higher yields observed in conventional management compared to ORG by other authors [25,27]. According to [27], strawberry yields are closely related to overall plant growth in terms of leaf area, petiole length and diameter, crown dry weight, root dry weight, and crown diameter. This fact further supports the hypothesis that higher yields achieved under the INT management treatments employed in the present trial are the result of the fastest and higher plant growth, as indicated by leaf area and plant weight measurements. Similar higher leaf area and plant dry weight have been reported under conventional farming, although there are not many data on the comparison of INT versus ORG [4]. Nonetheless, there are reports of ORG and conventional management of strawberries resulting in similar yields [21].

Fruit weight and dimensions did not differ among treatments, indicating that growing fruits were equally supplied with nutrients and assimilates under all cultivation management treatments. Taking into account that the yield was higher under INT management and that both leaf area and the number of fruits per plant were also higher, the assumption of an unhindered supply of assimilates to the fruits seems logical. Similar fruit weight has was reported in [21] working with conventional versus organic strawberries, whereas lower fruit weight under ORG management was reported in [26] and ascribed to the reduced nutrient availability under ORG farming.

In the present trial, the lower $\mathrm{N}$ and $\mathrm{K}$ concentration in the leaves of ORG plants compared to I-ACT could justify the lower yield, which, in turn, balanced any possible reduction in fruit weight. This is further justified by the similar fruit DW percentage determined in all treatments, indicating that there were not any restrictions of assimilate supply to the fruits. There have been reports of ORG-produced strawberry fruits exhibiting higher dry weight than conventionally produced strawberries $[4,19,26,28]$, but the majority of the literature connects these findings with a smaller fruit size under ORG management [28], which was not the case here. This indicates that like in INT management, where several differences were detected among the two INT practices applied here, in many measured parameters, the nutrient-supply strategy employed under each cultivation management treatment strongly defines plant growth and fruit development.

Fruit firmness did not differ among treatments, as has been reported by other researchers [28]. According to [8], smaller fruits tend to be firmer than larger fruits, but as fruits produced in this trial under both ORG and INT management were of similar growth, this justifies the similar firmness determined. However, according to [29], chemical fertilization tends to produce fruits of higher firmness, leading to the assumption that INT-produced fruits would be firmer. Nonetheless, one must take into account that $\mathrm{Ca}$ is a major component of fruit, which defines its firmness, and that there was not any difference among treatments concerning its concentration in the leaves. Furthermore, as ORG plants produced fewer fruits, the available Ca for these fruits seemed to be enough to keep them as firm as the fruits produced under chemical-fertilizer addition in INT management.

In the present trial, fruits produced under all treatments did not exhibit significant differences concerning color attributes. Similar results have been reported in strawberries cultivated under ORG and conventional management [28], although the more vivid color of ORG-cultivated strawberries has also been reported $[5,6,19,26]$, as well as lower L, chroma, and hue values [5].

Organoleptic characteristics of the fruits were found to be similar among treatments, and this was further confirmed by the similar results of panelist scores. There are reports that ORG-produced fruits are characterized by higher TSS content and lower TA $[6,19,26,30]$, 
whereas [13,31] did not find any significant differences, as in the present trial. According to [26], the higher TSS content of ORG fruits is attributed to their lower water content. In the present trial, fruits from all treatments exhibited a similar DW percentage, indicating that there was no difference in the water percentage of the fruits, therefore justifying the similar TSS values reported here. There are conflicting reports on the effect of cultivation management on TA, as lower, higher, an no differences have been found $[19,26,32,33]$.

ORG-produced fruits exhibited higher total flavanol content, as well as higher antioxidant capacity (measured by FRAP assay), compared to integrated fruits, irrespective of the scheme used (ACT or AGR). Similar results were reported in [2], and the authors attributed this superiority to the higher content of anthocyanins found in ORG-cultivated strawberries, whereas the higher antioxidant activity of ORG products was also reported in other species [34].

However, this was not the case in the present experiment, as there was not any significant difference between ORG and integrated management regarding anthocyanin content. The higher flavanol concentration found in ORG fruits could be the reason for their higher antioxidant capacity. The higher antioxidant capacity of ORG strawberry fruits was also reported in [9], and the authors attributed it to the higher determined flavonoid content. Generally, it is believed that subjecting plants to stressful conditions leads to an upregulation of phenolic biosynthesis, which serves as a defense substance $[5,7,8,35]$. Thus, under ORG cultivation practice, the biotic pressure by pests and diseases is expected to be greater than that under INT practice, leading to a higher accumulation of defense substances in the fruit. Furthermore, it has been found that the restricted use of phytosanitary products and chemical fertilizers in organic berry production accelerates the biosynthesis of phenolic compounds, leading to higher levels than under conventional practice [15,32].

However, in the present study, all biotic stress factors were successfully managed under both ORG and integrated cultivation management treatments, suggesting that there was no need for the plant to engage its defense arsenal [9]. Similar results have been reported by other researchers, who did not find any significant difference between the various cultivation management treatments or found less total phenolic compounds concentration in ORG produced fruits, such as in strawberries $[5,15,33,36]$ and other plant species [5,37-39]. However, others have reported the superiority of ORG-produced fruits over conventionally produced fruits in terms of concentrations of phenolic compounds $[2,7,9,28]$.

It must be noted that most studies compare ORG against conventional practice, where the adoption of sustainable practices, such as organic matter application, pest repellents, etc., is almost zero, whereas studies comparing ORG and INT management in strawberry culture are scarce, making it difficult to produce reasonable comparisons. Generally, data on the concentration of the phenolic compound in fruits and berries cultivated under different management treatments (especially conventionally versus ORG) are conflicting [18].

Another human-health-promoting molecule that is a valuable constituent of many fruits and vegetables is ascorbic acid. In the present trial, no difference was detected among treatments, and the same stood for all other organic acids detected. There are many reports on the superiority of ORG-produced fruits and vegetables over conventional cultivation practice regarding ascorbic acid concentration [2,6,7,32]; however, Asami et al. [7] pointed out the superiority of sustainable (similar to INT management practiced here) over conventional management, which supports the present findings. Furthermore, results similar to ours have been reported by others [26,40], although working with ORG and conventionally produced strawberries, whereas $[20,29]$ found a lower concentration of ascorbic acid in ORG-produced strawberries, obscuring, even more, the effects of cultivation management on its concentration in the fruit.

Carbohydrates, as well as the sweetness index of the ORG-cultivated fruits, were found to be, in most cases, higher those of I-AGR-cultivated fruits and similar to those determined under I-ACT practice. According to [29], the combination of chemical fertilizers plus organic matter in three strawberry cultivars led to a similar concentration of sugars to those measured under ORG fertilization, with similar conclusions reported by others $[10,15,18,28]$. 
On the other hand, [19] reported that ORG-produced strawberries have higher sugar concentrations than conventionally produced strawberries. This was also the case when ORG management was compared with INT management [10]. Cultivation management and its inputs play a significant role in the overall performance of the plant and the quality of the fruit produced.

Because the combined use of organic resources and mineral fertilizers has been promoted in the last twenty years, integrated soil fertility management (ISFM) is a component factor of sustainable intensification of agriculture to achieve satisfactory crop yields and efficient fertilizer use. Various organic resources (ORs), ranging from animal manures and crop residues to fungal biomass, have been used as major soil nutrient sources in both cultivation practices, organic and integrated. The results of this study demonstrate that the plant nutrition status of INT treatments was enhanced by the positive interactions between mineral fertilizers and organic inputs, resulting in higher $\mathrm{N}, \mathrm{K}, \mathrm{Fe}$, and $\mathrm{Mn}$ content. In support, several studies have observed that plant nutrient content was greater following the combined application of ORs and mineral fertilizers compared to the addition of either resource alone [41,42]. Nevertheless, the differential yield responses and plant nutrition following OR application seem to be attributed mainly to the wide variation of nutrient content, as well as the interactive effects of the soil chemical properties, OR rate, and quality [43].

Application of chicken manure and inorganic fertilizers (I-ACT) in the soil supported superior yield, as evidenced by the high content of $\mathrm{N}, \mathrm{K}, \mathrm{Fe}$, and $\mathrm{Mn}$ in strawberry leaves. These findings agree with studies by Yaldiz et al. [44] and Aliyu [45], who found that chicken manure as a valuable organic material increases the nutritional status of plants in integrated farming systems.

The application of Agrobiosol (OM 88\%) slightly increased SOM content compared to the ORG treatment, although the increase was not statistically significant. Other similar studies have reported increases in SOC and total $\mathrm{N}$ under long-term experiments treated with organic materials alone or in combination with fertilizer input. The organic fertilizer Guanito increased available P concentration up to $100 \mathrm{mg} \mathrm{kg}^{-1}$, indicating that soil in ORG management retained more available $\mathrm{P}$ at the end of the experiment. This was probably due to the enhanced microbial activity that released P during mineralization, a common phenomenon in soils with additions of organic materials. There were marked differences in soil P concentration between the organic and integrated treatments, as the phosphorus of Guanito is completely organic and not subjected to immobilization processes by soil constituents. Despite the different nature of organic amendments in I-ACT and I-AGR, which may be important for available $\mathrm{P}$, these treatments seem to increase available soil $P$ concentration equally, as they contain very similar $\mathrm{P}$ quantities. It should be noted that in our experiment, the soil properties, including $\mathrm{CaCO}_{3}$ content, provide strong evidence for fixation of inorganic phosphorus provided by chemical fertilizers in insoluble forms as calcium phosphates [46,47]. Despite significant increases in soil P, no differences in plant tissue $\mathrm{P}$ were observed, as previously supported by Hargraves et al. [48]. This is also the case for the other nutrients, supporting the findings of Niskanen and Dris [49] that there was a poor correlation between the concentrations of leaf and soil nutrients in strawberry.

Treatment effects were not observed on soil $\mathrm{pH}$, as the soil was calcareous with a high content of $\mathrm{CaCO}_{3}(26 \%)$ and therefore had a strong buffering capacity. However, the addition of Activit to the soil increased its electrical conductivity (EC) above the critical value of $4 \mathrm{mS} \mathrm{cm}^{-1}$. Watanabe et al. [50], in evaluating the effect of chicken manure on soil conductivity, found that the use of chicken manure stimulated the buildup of soluble salts in the soil, as was also demonstrated in our study.

Overall, INT management seemed to enhance plant growth and yield compared to ORG, which cannot be solely attributed to the nutrition of the plant, as was shown by both plant nutrient status and soil nutrient concentration. Similar results have been reported by other researchers, who attributed the differences found among organic sources to the 
different induction of soil enzyme activities, soil microbial community composition, soil plant hormone concentration, nutrient use efficiency, etc. [50-54].

\section{Conclusions}

Cultivation management influenced plant growth and nutrition, fruit quality, and soil physicochemical properties. The nutrient inputs used in each type of management seem to influence the aforementioned parameters to varying extents. ORG-produced strawberry fruits were clearly distinguished from those produced under INT management, showing low yield and fruit number per plant; high total flavanol concentration and antioxidant capacity (measured by FRAP assay); and high glucose, fructose, total sugars, sweetness index, and total organic acid concentration (compared to I-AGR only). All these differences were enough to separate ORG from the two INT treatments, revealing the significant role played by management in fruit quality and production. On the other hand, the panelists did not detect any significant difference in sensory attributes of fruits produced under either INT or ORG cultivation management treatments, partly justifying the belief of those who claim that the superiority of ORG-produced plant products lies in the zero pesticide residues and not in fruit quality. Nonetheless, when the plant nutrient status, along with soil physicochemical properties, was taken into account, it became clear that the fertilization management and especially the source of organic matter added, even within the same cultivation practice (i.e., INT), is enough to produce significant differences among treatments. In conclusion, it seems that INT-cultivated plants of cv. Camarosa produced higher yields of a high-quality product, but the fertilization strategy employed may be influence several of the yield components, indicating that the right choice of nutrient sources is a critical factor, even under INT management.

Author Contributions: Conceptualization, P.A.R.; methodology, P.A.R. and D.G.; software, P.A.R.; validation, P.A.R. and D.G.; formal analysis, P.A.R., A.T., E.K., P.P., A.P. and D.G.; investigation, P.A.R., A.T., E.K., P.P., A.P. and D.G.; data curation, P.A.R., A.T., E.K., P.P., A.P., M.Z. and D.G.; writing — original draft preparation, P.A.R., M.Z. and D.G.; writing—review and editing, P.A.R., M.Z. and D.G.; visualization, P.A.R.; supervision, P.A.R. and D.G.; project administration, P.A.R. and D.G.; funding acquisition, P.A.R. and D.G. All authors have read and agreed to the published version of the manuscript.

Funding: This research received no external funding.

Institutional Review Board Statement: Not applicable.

Data Availability Statement: P.A.R. and D.G. are responsible for data keeping, and data are available upon request.

Acknowledgments: We would like to thank Georion SA for kindly providing us with the plant material needed.

Conflicts of Interest: The authors declare no conflict of interest.

\section{References}

1. D'Urso, G.; d'Aquino, L.; Pizza, C.; Montoro, P. Integrated mass spectrometric and multivariate data analysis approaches for the discrimination of organic and conventional strawberry (Fragaria ananassa Duch.) crops. Food Res. Int. 2015, 77, 264-272. [CrossRef]

2. Fernandes, V.C.; Domingues, V.F.; de Freitas, V.; Delerue-Matos, C.; Mateus, N. Strawberries from integrated pest management and organic farming: Phenolic composition and antioxidant properties. Food Chem. 2012, 134, 1926-1931. [CrossRef] [PubMed]

3. Domingues, A.R.; Vidal, T.C.M.; Hata, F.T.; Ventura, M.U.; Gonçalves, L.S.A.; Silva, J.B. Postharvest quality, antioxidant activity and acceptability of strawberries grown in conventional and organic systems. Braz. J. Food Technol. 2018, 21, e2017154. [CrossRef]

4. Conti, S.; Villari, G.; Faugno, S.; Melchionna, G.; Somma, S.; Caruso, G. Effects of organic vs. conventional farming system on yield and quality of strawberry grown as an annual or biennial crop in southern Italy. Sci. Hortic. 2014, 180, 63-71. [CrossRef]

5. Crecente-Campo, J.; Nunes-Damaceno, M.; Romero-Rodríguez, M.A.; Vázquez-Odériz, M.L. Color, anthocyanin pigment, ascorbic acid and total phenolic compound determination in organic versus conventional strawberries (Fragaria $\times$ ananassa Duch, $\mathrm{cv}$ Selva). J. Food Compos. Anal. 2012, 28, 23-30. [CrossRef] 
6. Abu-Zahra, T.R.; Al-Ismail, K.; Shatat, F. Effect of organic and conventional systems on fruit quality of strawberry (Fragaria $\times$ ananassa duch) grown under plastic house conditions in the jordan valley. Acta Hortic. 2007, 741, 159-171. [CrossRef]

7. Asami, D.K.; Hong, Y.-J.; Barrett, D.M.; Mitchell, A.E. Comparison of the total phenolic and ascorbic acid content of freeze-dried and air-dried marionberry, strawberry, and corn grown using conventional, organic, and sustainable agricultural practices. $J$. Agric. Food Chem. 2003, 51, 1237-1241. [CrossRef]

8. Mditshwa, A.; Magwaza, L.S.; Tesfay, S.Z.; Mbili, N. Postharvest quality and composition of organically and conventionally produced fruits: A review. Sci. Hortic. 2017, 216, 148-159. [CrossRef]

9. Jin, P.; Wang, S.Y.; Wang, C.Y.; Zheng, Y. Effect of cultural system and storage temperature on antioxidant capacity and phenolic compounds in strawberries. Food Chem. 2011, 124, 262-270. [CrossRef]

10. Akšić, M.F.; Tosti, T.; Sredojević, M.; Milivojević, J.; Meland, M.; Natić, M. Comparison of sugar profile between leaves and fruits of blueberry and strawberry cultivars grown in organic and integrated production system. Plants 2019, 8, 205. [CrossRef]

11. Szelagg-Sikora, A.; Sikora, J.; Niemiec, M.; Gródek-Szostak, Z.; Kapusta-Duch, J.; Kuboń, M.; Komorowska, M.; Karcz, J. Impact of Integrated and Conventional Plant Production on Selected Soil Parameters in Carrot Production. Sustainability 2019, $11,5621$. [CrossRef]

12. Kovačević, D.B.; Putnik, P.; Dragović-Uzelac, V.; Vahčić, N.; Babojelić, M.S.; Levaj, B. Influences of organically and conventionally grown strawberry cultivars on anthocyanins content and color in purees and low-sugar jams. Food Chem. 2015, 181, 94-100. [CrossRef] [PubMed]

13. Tittarelli, F.; Ceglie, F.G.; Ciaccia, C.; Mimiola, G.; Amodio, M.L.; Colelli, G. Organic strawberry in Mediterranean greenhouse: Effect of different production systems on soil fertility and fruit quality. Renew. Agric. Food Syst. 2016, 32, 485-497. [CrossRef]

14. Gomiero, T. Food quality assessment in organic vs. conventional agricultural produce: Findings and issues. Appl. Soil Ecol. 2018, 123, 714-728. [CrossRef]

15. Häkkinen, S.H.; Törrönen, A.R. Content of flavonols and selected phenolic acids in strawberries and Vaccinium species: Influence of cultivar, cultivation site and technique. Food Res. Int. 2000, 33, 517-524. [CrossRef]

16. Huber, M.; Rembiałkowska, E.; Średnicka, D.; Bügel, S.; van de Vijver, L.P.L. Organic food and impact on human health: Assessing the status quo and prospects of research. NJAS Wagening. J. Life Sci. 2011, 58, 103-109. [CrossRef]

17. Looser, N.; Kostelac, D.; Scherbaum, E.; Anastassiades, M.; Zipper, H. Pesticide residues in strawberries sampled from the market of the Federal State of Baden-Württemberg in the period between 2002 and 2005. J. Verbraucherschutz Lebensmittelsicherheit 2006, 1, 135-141. [CrossRef]

18. Olsson, M.E.; Andersson, C.S.; Oredsson, S.; Berglund, R.H.; Gustavsson, K.-E. Antioxidant levels and inhibition of cancer cell proliferation in vitro by extracts from organically and conventionally cultivated strawberries. J. Agric. Food Chem. 2006, 54, 1248-1255. [CrossRef]

19. Cayuela, J.A.; Vidueira, J.M.; Albi, M.A.; Gutiérrez, F. Influence of the Ecological Cultivation of Strawberries (Fragaria $\times$ Ananassa Cv. Chandler) on the Quality of the Fruit and on Their Capacity for Conservation. J. Agric. Food Chem. 1997, 45, 1736-1740. [CrossRef]

20. Cardoso, P.C.; Tomazini, A.P.B.; Stringheta, P.C.; Ribeiro, S.M.R.; Pinheiro-Sant'Ana, H.M. Vitamin C and carotenoids in organic and conventional fruits grown in Brazil. Food Chem. 2011, 126, 411-416. [CrossRef]

21. Kahu, K.; Klaas, L.; Kikas, A. Effect of cultivars and different growing technologies on strawberry yield and fruit quality. Agron. Res. 2010, 8, 589-593.

22. Roussos, P.A.; Denaxa, N.-K.; Ntanos, E.; Tsafouros, A.; Mavrikou, S.; Kintzios, S. Organoleptic, nutritional and anti-carcinogenic characteristics of the fruit and rooting performance of cuttings of black mulberry (Morus nigra L.) genotypes. J. Berry Res. 2020, 10, 77-93. [CrossRef]

23. Keutgen, A.; Pawelzik, E. Modifications of taste-relevant compounds in strawberry fruit under NaCl salinity. Food Chem. 2007, 105, 1487-1494. [CrossRef]

24. Ntanos, E.; Kekelis, P.; Assimakopoulou, A.; Gasparatos, D.; Denaxa, N.-K.; Tsafouros, A.; Roussos, P.A. Amelioration Effects against salinity stress in strawberry by bentonite-zeolite mixture, glycine betaine, and bacillus amyloliquefaciens in terms of plant growth, nutrient content, soil properties, yield, and fruit quality characteristics. Appl. Sci. 2021, 11, 8796. [CrossRef]

25. Demirsory, L.; Demirsoy, H.; Balci, G. Different growing conditions affect nutrient content, fruit yield and growth in strawberry. Pak. J. Bot. 2011, 44, 125-129.

26. Barbieri, G.; Colonna, E.; Rouphael, Y.; Pascale, S.D. Effect of the farming system and postharvest frozen storage on quality attributes of two strawberry cultivars. Fruits 2015, 70, 351-360. [CrossRef]

27. Gliessman, S.R.; Werner, M.R.; Allison, J.; Cochran, J. A comparison of strawberry plant development and yield under organic and conventional management on the central California coast. Biol. Agric. Hortic. 1996, 12, 327-338. [CrossRef]

28. Reganold, J.P.; Andrews, P.K.; Reeve, J.R.; Carpenter-Boggs, L.; Schadt, C.W.; Alldredge, J.R.; Ross, C.F.; Davies, N.M.; Zhou, J. Fruit and soil quality of organic and conventional strawberry agroecosystems. PLoS ONE 2010, 5, e12346. [CrossRef]

29. Kilic, N.; Burgut, A.; Gündesli, M.A.; Nogay, G.; Ercisli, S.; Kafkas, N.E.; Ekiert, H.; Elansary, H.O.; Szopa, A. The effect of organic, inorganic fertilizers and their combinations on fruit quality parameters in strawberry. Horticulturae 2021, 7, 354. [CrossRef]

30. Hargreaves, J.C.; Adl, M.S.; Warman, P.R.; Rupasinghe, H.P.V. The effects of organic and conventional nutrient amendments on strawberry cultivation: Fruit yield and quality. J. Sci. Food Agric. 2008, 88, 2669-2675. [CrossRef] 
31. Khalil, H.A.; Hassan, S.M. Ascorbic acid, $\beta$-carotene, total phenolic compound and microbiological quality of organic and conventional citrus and strawberry grown in Egypt. Afr. J. Biotechnol. 2015, 14, 272-277. [CrossRef]

32. Nunes, M.C.N.; Delgado, A. quality of organic compared to conventionally grown strawberries at the retail level. Acta Hortic. 2014, 1049, 723-730. [CrossRef]

33. Kobi, H.; Martins, M.; Silva, P.; Souza, J.; Carneiro, J.; Heleno, F.; Queiroz, M.; Costa, N. Organic and conventional strawberries: Nutritional quality, antioxidant characteristics and pesticide residues. Fruits 2018, 73, 39-47. [CrossRef]

34. Yu, X.; Guo, L.; Jiang, G.; Song, Y.; Muminov, M.A. Advances of organic products over conventional productions with respect to nutritional quality and food security. Acta Ecol. Sin. 2018, 38, 53-60. [CrossRef]

35. Dixon, R.A.; Paiva, N.L. Stress-Induced Phenylpropanoid Metabolism. Plant Cell 1995, 7, 1085-1097. [CrossRef] [PubMed]

36. Törrönen, R.; Määttä, K. Bioactive substances and health benefits of strawberries. Acta Hortic. 2002, 567, 797-803. [CrossRef]

37. You, Q.; Wang, B.; Chen, F.; Huang, Z.; Wang, X.; Luo, P.G. Comparison of anthocyanins and phenolics in organically and conventionally grown blueberries in selected cultivars. Food Chem. 2011, 125, 201-208. [CrossRef]

38. Vrček, I.V.; Bojić, M.; Žuntar, I.; Mendaš, G.; Medić-Šarić, M. Phenol content, antioxidant activity and metal composition of Croatian wines deriving from organically and conventionally grown grapes. Food Chem. 2011, 124, 354-361. [CrossRef]

39. Wang, S.Y.; Chen, C.T.; Sciarappa, W.; Wang, C.Y.; Camp, M.J. Fruit quality, antioxidant capacity, and flavonoid content of organically and conventionally grown blueberries. J. Agric. Food Chem. 2008, 56, 5788-5794. [CrossRef]

40. Hakala, M.; Lapveteläinen, A.; Huopalahti, R.; Kallio, H.; Tahvonen, R. Effects of varieties and cultivation conditions on the composition of strawberries. J. Food Compos. Anal. 2003, 16, 67-80. [CrossRef]

41. Chivenge, P.; Vanlauwe, B.; Six, J. Does the combined application of organic and mineral nutrient sources influence maize productivity? A meta-analysis. Plant Soil 2011, 342, 1-30. [CrossRef]

42. Abid, M.; Batool, T.; Siddique, G.; Ali, S.; Binyamin, R.; Shahid, M.J.; Rizwan, M.; Alsahli, A.A.; Alyemeni, M.N. Integrated nutrient management enhances soil quality and crop productivity in maize-based cropping system. Sustainability 2020, 12, 10214 [CrossRef]

43. Gram, G.; Roobroeck, D.; Pypers, P.; Six, J.; Merckx, R.; Vanlauwe, B. Combining organic and mineral fertilizers as a climate-smart integrated soil fertility management practice in sub-Saharan Africa: A meta-analysis. PLoS ONE 2020, 15, e0239552. [CrossRef] [PubMed]

44. Yaldız, G.; Çamlıca, M.; Özen, F.; Eratalar, S.A. Effect of poultry manure on yield and nutrient composition of sweet basil (Ocimum basilicum L.). Commun. Soil Sci. Plant Anal. 2019, 50, 838-852. [CrossRef]

45. Aliyu, L. Effect of organic and mineral fertilizers on growth, yield and composition of pepper (Capsicum annuum L.). Biol. Agric. Hortic. 2000, 18, 29-36. [CrossRef]

46. Antoniadis, V.; Koliniati, R.; Efstratiou, E.; Golia, E.; Petropoulos, S. Effect of soils with varying degree of weathering and pH values on phosphorus sorption. CATENA 2016, 139, 214-219. [CrossRef]

47. Hu, Z.; Ding, Z.; Al-Yasi, H.M.; Ali, E.F.; Eissa, M.A.; Abou-Elwafa, S.F.; Sayed, M.A.; Said, M.T.; Said, A.A.; Ibrahim, K.A.M.; et al. Modeling of phosphorus nutrition to obtain maximum yield, high $\mathrm{p}$ use efficiency and low P-loss risk for wheat grown in sandy calcareous soils. Agronomy 2021, 11, 1950. [CrossRef]

48. Hargraves, J.C.; Adl, M.S.; Warman, P.R. Are compost teas an effective nutrient amendment in the cultivation of strawberries? Soil and plant tissue effects. J. Sci. Food Agric. 2009, 89, 390-397. [CrossRef]

49. Niskanen, R.; Dris, R. Nutritional status of strawberry fields. Acta Hortic. 2002, 567, 439-442. [CrossRef]

50. Watanabe, H.; Hoshino, K.; Adachi, Y. Effects of poultry manure on soil solution electrical conductivity and early growth of Monochoria vaginalis. Plant Prod. Sci. 2017, 20, 67-71. [CrossRef]

51. Kelderer, M.; Topp, A.; Lardschneider, E.; Rainer, A.; Matteazzi, A. Organic apple tree nutrition: Comparison of different organic fertilizers, application timing and rate, and soil management techniques: Results of a 5 year field study. In Proceedings of the 16th International Congress on Organic Fruit Growing, Hohenheim, Germany, 17-19 February 2014; pp. 116-126.

52. Wang, B.; Liu, H.; Cai, C.; Thabit, M.; Wang, P.; Li, G.; Duan, Z. Effect of dry mycelium of Penicillium chrysogenum fertilizer on soil microbial community composition, enzyme activities and snap bean growth. Environ. Sci. Pollut. Res. 2016, 23, 20728-20738. [CrossRef] [PubMed]

53. Nardi, S.; Morari, F.; Berti, A.; Tosoni, M.; Giardini, L. Soil organic matter properties after 40 years of different use of organic and mineral fertilizers. Eur. J. Agron. 2004, 21, 357-367. [CrossRef]

54. Nardi, S.; Pizzeghello, D.; Ertani, A. Hormone-like activity of the soil organic matter. Appl. Soil Ecol. 2018, 123, 517-520. [CrossRef] 